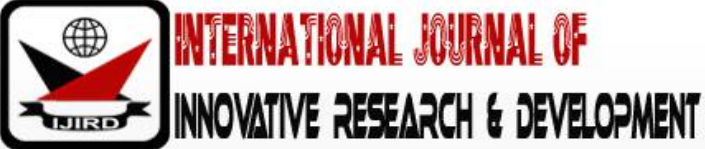

ISSN 2278 - 0211 (Online)

\section{Contentious Issues in DNA Testing: A Legal Pointer to Igbo People and Their Values}

\author{
Felicia Anyogu \\ Professor, Department of laws, Nnamdi Azikiwe University, Awka, Nigeria \\ MVC Ozioko \\ Senior Lecturer, Nnamdi Azikiwe University, Awka, Nigeria
}

\begin{abstract}
:
In an interview granted to information.com by a DNA Expert, he claimed that three out of ten Nigerian men are not the biological fathers of their children. Similarly, three out of every ten children are not fathered by men they have seen as their biological fathers in Nigeria. Now globally the general statistics by the American Association of Blood Banks stands at 100,000 out of 300,000 men not being the actual fathers of their presumed children. It would seem that paternity test has become an issue in Nigeria as some Laboratories claim to test 15 to 20 people every week. In some of the cases the men may have trained and taken care of the children to adult age. Paternity testing has become an essential part of the global community, Nigeria inclusive. This paper will examine the essence of paternity testing, circumstances warranting it and the socio, economic, cultural and legal consequences of DNA testing among the Igbo people. Recommendations shall also be proffered as a forward
\end{abstract}

Keywords: DNA paternity testing, human rights, legal pointer, Igbos, Nigeria

\section{Introduction}

The multifaceted nature of human beings has given rise to a lot of issues that one never even imagined could arise. One of the worrying events today is the rate of divorce among married couples. A high percentage of these break-downs are caused by infidelity. Some times in funerals, you find the wife of the deceased seated in mourning as tradition demands, and some strange children (not hers) are led in to mourn their dead fathers (2004). The greed of man these days has also thrown people into sometimes rejecting their own. These and so many other instances may necessitate that the truth be found. This is no longer the age where men reject or accept children without much questioning. Thanks to advances in medical technology, a paternity test can now be run to ascertain the truth in all doubtful cases. The DNA paternity testing is the use of DNA profiling (known as genetic finger printing) to determine whether two individuals could be parent and child. While the paternity testing establishes fatherhood, maternity established motherhood. The DNA testing is at the moment the mostly acclaimed, advanced and accurate means to determine parentage and it can also be performed even while a woman is still pregnant (2012). When people are young and restless, they might make out with people they hardly know much about at parties, and other very transient circumstances. In such a situation, paternity testing becomes very important when faced with the announcement of the arrival of one's new born baby. The Igbo people and generally most Nigerian communities lead communal lives; in this where one comes from and their parental pedigree is very important. In the Igbo community, children are cherished and are highly valued. This paper seeks to examine the effect of DNA Paternity testing and the need to really want to know the paternity of someone vis-à-vis the values of the Igbo people in relation to children.

\section{Conceptual Framew ork}

\subsection{DNA}

DNA stands for Deoxyribonucleic Acid. It is a molecule that carries most of the genetic instructions used in the development; functioning and reproduction of all known living organisms and even some virus. Most DNA molecules consist of two biopolymer strands coiled around each other to form a double helix. The two DNA strands are known as polynucleotides since they are composed of simpler units called nucleotides (internet source). DNA usually occurs as linear chromosomes in eukaryotes and circular chromosomes in prokaryotes. The set of chromosomes in a cell makes up its genome and the human genome has approximately three billion base pairs of DNA arranged into 46 chromosomes (2001). The information carried by DNA is held in the sequence of pieces of DNA called genes. The expression of genes is influenced by how the DNA is packaged in chromosomes in a structure called chromatin. 


\subsection{Paternity Testing}

This is a technique used in finding out the likelihood of parentage. A paternity test establishes genetic proof of whether a man is the biological father of an individual while maternity testing does the same for the biological mother of an individual. Tests also exist to prove the possibility of grandparent/ grand child relationship. Various methods exist for this test and these include the ABO blood group typing, analysis of other proteins and enzymes or using human leukocyte antigens. DNA paternity testing seems to be currently the most adequate, reliable and advanced technology for determining parentage. The DNA test reads $0 \%$ where the alleged parent is not biologically related to the child while it reads $99.99 \%$ if the reverse is the case, and this is called the probability of parentage (internet source).

\subsection{Igbos}

The Igbo people occupying Igbo land are an ethnic group of southern Nigeria directly indigenous to East and West of the lower Niger River with a very significant population found in the eastern side of the river (2000). They speak Igbo which includes various shades and dialects of the language. The Igbos make up a population of 32 million. Presently they succinctly occupy about 5 states in Nigeria namely Anambra, Abia, Enugu, Ebonyi and Imo states. If the Igbo language is anything to go by, then Igbo-land could also claim part of Delta, Rivers and even Benue states. The Igbo's are mostly Christians and very few practice indigenous Igbo religion. The Igbos are one of the largest ethnic groups in Africa (2008). In Nigeria they are known for their industry and commercial prowess.

\subsection{Igbo People and their Values on Children}

For the Igbo man, marriage is primarily for procreation. Marriage occupies a pivotal position in the social economy of the Igbo people, and presents itself to igbo youths (both male and female) as an indispensable function in life, which should be carried out without delay at the appropriate age. Igbo people being deeply patriarchal, marriage seems to be a factor to fulfill the function of family continuation. Children are the medium through which this can be achieved. Every Igbo male and female want to get married and beget their own children as their own parents did and the parents (who would be grandparents) yearn for this. The importance of children in the lives of the Igbos is manifested in some Igbo names such as; Nwakaego (a child is more valuable than money); Nwabunwanne (a child is a sibling); Nwakasi (a child supersedes everything or is most precious); Nwa di uto (a child is sweet); Nwa di aguu (a child is desirable); Nwabuona (a child is a precious stone); and a host of other names depicting the importance of children. This has informed the disdain attached to a childless marriage and childlessness in general. Childlessness or the absence of a male child is at the root of the breakupof many marriages even though many people will not admit it is the main reason for the squabbles in the homes. Up to the present day, a woman does not feel secure in her home until she begets a child and more secure when she gives her husband a male child. This is when she becomes 'wife' to the husband's entire lineage. A childless woman is pitied, ridiculed and even scorned by various categories of people. She is pitied by the public, ridiculed by her rivals, and scorned by her in-laws. This state of affairs has informed the fact that some Igbo communities' welcome children and attach them to families no matter where they are coming from. The quest for having children is also probably one of the reasons why polygamy (polygyny) has persisted in the igbo society. This leads to a discourse on the various sources of children in Igbo land aside the primary, supreme and ultimate source (God).

\subsection{Sources of Children in Igbo Land}

\subsubsection{Children from Married Couple}

Most of the children in Igbo land are products of a married couple, in a monogamous marriage. This is marriage under the Act (2004) and the type defined in Hyde vs. Hyde ( ) as between one man and one woman for life to the exclusion of all others. Presumably, these are also the children that represent the notion and essence of marriage in Igbo land.

\subsubsection{Children Born by Unmarried Girls}

When a girl in Igbo land stays in her father's house and bears a child without a husband, that child is culturally assumed to belong to her maiden family. He or she is given the family name and everything pertaining to that child's life is regulated by the mothers' maiden family as if he or she was born by a male in the family.

\subsubsection{Children from Polygamous Homes}

These are homes where one man is married to several women. Unlike in the Muslim world where a man is entitled to marry four wives if he so desired, when an Igbo man decides to live a polygamous life, there is no regulation attached. He can marry as many as he wants. All the women will have as many children as they want even when the man is old and weak. This has led to the suspicion that such a man may not have fathered all his children.

\subsubsection{Children from Woman to Woman Marriage}

A widow who could not have an issue before the death of her husband is allowed by Igbo culture to marry a wife in the name of the dead husband to produce children in his name. Of course, these children will be fathered by different men both from inside and outside but they are all regarded as the dead man's children and therefore children of the family. This situation could also be at the instance of a woman whose brother died without a wife or a child. The woman is allowed by Igbo culture to marry a wife for her deceased brother to produce children in his name. Until recently as pronounced by the Supreme Court in Mojekwu vs. Ejikeme (2000) women in Igbo-land did not inherit their father's 
property. Such a woman would do this so that her mother's share in their father's estate would not go to other people. All these children are supposed to be precious to the Igbo society but when the chips are down, and coupled with complex human nature, children start being labeled 'originals' and 'counterfeits', especially in the area of kingship', 'Igweship' and in allocation of certain choice land especially where land is hard to come by in the particular community.

\subsection{Implications of DNA Paternity Testing in Igbo-Land}

The DNA paternity test seems to be a simple procedure, yet it can have profound effects on the lives involved. In the past, once marriage was established between a couple, many legal systems presumed the husband to be the father of any children born between them as long as the marriage subsisted. This is also the position in Nigeria. Unfolding events have shown that this is not always the position (personal knowledge). In most of these old cases, nothing was done. The old methods such as the ABO blood group, finger prints and others would only give the possibility of a range of people who could be the father of the person whose identity is in question. The DNA paternity testing comes with more precision as to parentage with a range of probability between 0 to $100 \%$. To date, it is the most accurate form of paternity testing but when the issue has to do with the Courts, the results have to be read and interpreted by the Courts and when the Nigerian factor steps in, the claim of absolute truth of the test will be highly compromised.

The world is continually developing, changing and with it, are the human beings in it. There is also the issue of population growth and the fact that earlier generations do not practice sustainable development. The effect is the depletion of family resources with the teeming family sizes. Family members now have to struggle over family lands and other resources. The effect is that people no longer want to tolerate those who do not rightly belong as some of them would say that the resources are not enough for the real owners. Law has also developed along with national and world development to the extent that people are becoming more aware of the fact that litigation is the most civilized method of settling disputes. Armed with this and the scientific invention of the DNA paternity testing, nothing stops a very bitter and ambitious member of a family from disputing the parentage of any member of the family, ultimately to prove that such a person is not a natural and biological member of the family. If this happens to a man who has grown up in a family believing that he biologically belongs, marries a wife in the family name and has children all bearing the family name, the embarrassment will be overwhelming. The Igbo community being essentially communal, such a person, if he is the proud type would want to trace his paternity and start all over there. This will not be an easy task at all. If he decides to brave it and stay, he may have to buy land in order to build his house in the community, and may not be able to speak out in the gathering of the kinsmen.

When a man suspects he may not be the father of any of his children, DNA paternity testing yields a veritable tool for confirmation. When this confirmation is made, the marriage may fall on the rocks. If the marriage subsists, the man may become very bitter and take it out on the child and the effect may be lasting on the child. On the other hand, the implications of DNA paternity testing can be enormous on those who impregnate girls and women and deny responsibility. Many girls have been rendered useless because of the burdens of unplanned parenthood. When it is the man's words against the woman's who is the father of her unborn child, the women bear the brunt of it. The DNA paternity test will help identify who at least the father of the child is, even though traditionally, such a child belongs to the mother's maiden family. With the DNA test, the father cannot continue to deny paternity of the child and when the father acknowledges paternity that removes the brand 'bastard' from the child.

\subsection{DNA Testing, a Human Rights Issue}

The belief that everyone by virtue of his or her humanity is entitled to certain human rights began during the era of renaissance humanism in the early modern period. The idea of human rights laid the foundation for the American and French revolutions opening up the initiation of the universal suffrage. The Paris Peace Conference of 1919 now gave rise to the League of Nations, which ultimately led to the Universal Declaration of Human Rights. This was not binding but subsequently produced many binding International and Regional Conferences, Treaties, Conventions and Covenants that are binding on State Parties. Based on the mandates of these international treaties, Nigerian Constitutions have always contained Chapters on human Rights from the 1960 Constitution to the present 1999 Constitution. Chapter IV of the 1999 Constitution contains the first generation rights or fundamental rights which are also said to be negative in that, they impose restraints on the state, but require no positive action for their enjoyment. These rights include right to life, right to fair hearing and right to private and family life. They also include right to freedom of thought, conscience and religion, right to freedom of expression and the press, right to peaceful assembly and association, right to freedom of movement and right to freedom from discrimination. They also include the right to acquire and won immovable property anywhere in Nigeria and the right not to have such property compulsorily acquired save in the manner and for the purpose prescribed a law that among other things requires the conditions stipulated under this section. The same chapter IV grants the High Court special jurisdiction on matter relating to the violation of any of these rights (1999 Constitution). This implies another right of the citizen to enforce these rights in Court.

Chapter II of the 1999 Constitution contains the unenforceable socio economic and cultural rights which are tagged the 'Fundamental Objectives and Directive Principles of State Policies' (1999 Constitution). The rights under Chapter II are a sine quo non to the recognition, enjoyment and enforcement of the rights in Chapter IV and yet they are made non-justiciable. This issue is whether any of the justiciable rights is likely to be affected by the issue of DNA paternity test. There don's seem to be any judicial authorities in Nigeria on this yet, but in a foreign case of Iyilik vs. turkey (2012) a man believed he was not the father of a daughter by his wife, a year later they got married. He went for a paternity test with the only available method at the time. He was told, he could be the father just as any other man with the same blood type could be. The domestic Courts consequently denied his request for contestation of paternity. In 2002, 
Mr. Iyilik sought to reopen the contest for paternity in view of new scientific developments, i.e. the possibility of undergoing a DNA test. He relied on an article of the Turkish Civil Procedural Code which allowed for reopening of any civil proceedings if the initial proceedings had constituted force majeure. The Courts however rejected his request relying on established jurisprudence of the Turkish Courts of Cassation to the effect that the state of scientific development and progress could not reveal any force majeure. Mr. Iyilik claimed a violation of his right to respect for his private life in front of the European Court of Human rights. The Court first acknowledged that it had established in several cases that a situation in which it was impossible to let the biological reality prevail over a legal positive obligations of the state under article 8 even having regard to the margin of appreciation that member states enjoy in this field. The Court however distinguished Iyilik's case from those earlier cases because Iyilik had no proof that he was in fact not the father of his said daughter. The Court therefore agreed with the domestic Courts seeing nothing arbitrary or disproportionate in the decision. Two judges dissented to this, emphasizing that the prevalence of the biological reality over legal presumptions of fatherhood is an established principle in the Court's case law and that this principle is not subject to consent of any other persons concerned even where they would have to undergo a DNA test. This case is to be distinguished from Paulik vs. Slovakia (2008). In Paulik and Slovakia he indeed obtained evidence to show he was not the father and his daughter was willing to under the DNA test while in Iyilik's case, he had no proof of not being the father, and the daughter was not willing to give up being his daughter and all that came with it.

In Cyprus, it is also reported that the Immigration Department is violating the human right to family life and privacy by forcing families with a foreign mother to undergo paternity testing at their expense to prove that the father is a Cypriot national, according to the Ombudswoman's office. Following these reports, an investigation was carried out by the ombudswoman Eliza Savvidou. The result was a condemning report against the department issued on October 31, 2012 which Savvidou said effectively violates human rights (internet source). The question one may ask is, if it is the right of a person to know if his supposed father is really his father. If a child is born into a marriage between a man and a woman, the presumption is that the child born is that of the man. This presumption is however rebuttable on proof by a test like DNA paternity test. In some cases, where paternity is an issue, the Court may order a DNA test, but in other cases especially where the child is a minor, the Court may decide that it is not in the best interest of the child to know, who his or her biological parents are. In Igbo-land the possible rights that could be violated are right to family and private life especially where the person (especially a man) is well settled in a family he thinks he belongs to. This could also lead to shock and emotional trauma perhaps amounting to emotional torture violating the right to dignity of the human person if Igbo values are anything to go by. People may believe it is a fundamental human right to know who one's biological parents are in satisfaction of the Right to respect for private and family life enshrined in the 1999 Constitution of Nigeria ( $\mathrm{C}_{23} \mathrm{LFN}$ 2004). This right obviously includes the right to information about one's identity. This right is however not absolute and other factors could override the right.

\subsection{In the Best Interest of the Child}

\subsubsection{Who Is a Child in Nigeria?}

The ordinary dictionary meaning of a child is; A boy or girl at any age between infancy and adolescence; a new born infant; a person of any age in relation to his parents; a father or disciple.

A child following from the above definition is susceptible to two basic meanings; chronological age; and that of being the offspring of another, either by birth or by adoption. In Ogg-Moss vs. R (1984) the then Chief Justice of the Supreme Court of Canada Brian Dickson described a child more succinctly thus;

Both in common parlance and as a legal concept, the term child has two primary meanings. One refers to chronological age and is the converse of the term adult: the other refers to lineage and is the reciprocal of the term parent: a child in the first sense was defined at common law as a person under the age of fourteen.... A child in the second sense was defined at common law as the legitimate offspring of a parent, but in most jurisdiction's, this definition has been amended by statute to constitute all offspring, whether legitimate or not as the children of their natural or adoptive parents.

The latter part of this definition tallies with the practice in some parts of Igbo-land. In Arochukwu in the early days there was a festival where human beings were used as sacrifice and so the more there number of people in a family the easier it was to get a sacrifice. The families did not care where children came from. They just accepted all of them. While this was in order for the family to have enough illegitimates to use as sacrifice this culture of accepting children no matter where they came from has remained with them even long after the sacrifices have stopped. Igbos abides by both their customs and the laws of Nigeria that are applicable to their part of the country. Who a child is in Nigeria depends on the context in which it appears. What may be held to be the age of majority for one legal purpose may not be so held for another. The issue of contract is governed by the infant's laws of the various states in Nigeria, and these were codified from the Infants Relief Act, 1874 which is a Statute of General Application. This defines an infant as a person under 21 years of age. This was substantiated in Labinjoh vs. Abake (1924) where it was stated that for the purposes of contract a child is a person under 21 years. The Nigerian Labour Act (Cap LI LFN 2000) defines a child as a young person under the age of 12 years, however for purposes of employment one remains a child until 16 years. For matters relating to citizenship, the 1999 constitution of the federal Republic of Nigeria defines a person of full age as one who has attained eighteen years and above. For purposes for franchise the same contrition prescribed 18 years as the age of maturity. The Marriage Act ( $\left.\mathrm{M}_{6} \mathrm{LFN} 2004\right)$ prescribes 21 years as the e requiring no parental consent for marriage. By implication, the age of informed consent for marriage is 21. Customary rules adopt the age of puberty which is 12 for girls and 14 for boys. At common law the age of maturity is 21 being the age at which it is presumed that a person can manage his own affairs. 
Both the United Nations Convention on the Rights of the Child (1989) and the African Charter on Human and Peoples' Right (1981) peg the age of majority at 18. Nigeria in line with the International standards declared 18 years as the age of majority in the Child's Right Act 2003, although the application of this Act is not uniform in Nigeria. Many states have adopted it as their state law, while others have not. For the purposes of this paper, a child shall also include anybody whose paternity is sought to be ascertained no matter how old they are. The writes believe at DNA paternity testing should be done in the best interest of a child. If doing it will give the child identity which he or she does not have and also mean better life for the child, then it should be carried out. Where the parentage of a child who has established himself in a family is sought for selfish reasons and he/ she does not give consent, it should be allowed to be done. Sometimes, it is not in the interest of a child to know who his or her mother is even where the child is adopted. The ability of people to take shocks varies. If the child's mother was a mad woman in the streets who you cannot trace anymore, what is the point in telling him or her if the child is well settled. The value placed on children in Igbo-land demands that DNA patterning testing should only be done in the best interest of the child.

\section{Concluding Remarks}

The Igbo culture and indeed Igbo communities are very warm, even to visitors. Children occupy a pivotal position among the Igbos as depicted by the names they give to children. The Igbo culture and tradition places a premium on the continuation of lineage, and this is manifested in Igbo names like Afamefuna, Amaechina, Uzoechina and Okpomechina. This is so paramount that some communities embrace children into their families, no matter how they are conceived as long as their mothers are married into the family by whatever means. Technological advancement, legality, and population in conspiracy with human nature have made it necessary that circumstance of birth has to be given consideration in certain issues also orchestrated by the same culture. The issue of DNA paternity testing has made it difficult for children to be passed on to or foisted on families when they don't want them. It is also pertinent that technological advancement does not eat into the fabrics of established legal principles and some humane cultural acceptances. The writers are not however saying that natural parents should be sacrificed on the altar of culture, rebuttable legal principles or other forms of parenting. It is humbly submit that all should be in the best interest of the child. If DNA paternity test will mean a child going into limbo or hell completely, it is humbly submitted that the child be left where he was. To find out after many years of belonging to a family and carrying out life processes in the family name, that one is not a natural or biological child of the father of the family; will certainly be shocking and emotion draining. It is therefore submitted that counseling sessions be provided for such people before the DNA paternity test. Scientific and Technological development is a welcome affair in every society, and it is hoped that in time, the Igbo society and culture will also develop to match the usefulness of these developments.

\section{References}

i. Witnessed by writer herself. Those children were purported to be children of the deceased, with some other women unknown to the deceased's wife and out of their wedlock."Paternity Blood Test.

ii. Parcell, Adam "DNA" Basic biology also at DNA - Wikipedia the free encyclopedia https:/ / en.wikioedua.org/ wiki/ DNA accessed.

iii. Venter J C, Adams MD et al 2001" The sequence of the human genome" Science 291 5507, 1304-51, Bibcode.

iv. "Probability of Paternity" Dr. Ron Ostrowki, UMC Charlotte (http:/ / bioferensics.com/ conference/ patrnity/ ).

v. Ctigere, Mkem Hyginus 2000. Foreign Missionary Background and Indigenous Evangelization in Igbo land: Igbo land and the Igbo people of Nigeria, Transaction Publishers, USA p. 17.

vi. William, Lizzy 2008, Nigeria: The Bratt Travel Guides p. 32. Marriage Act Cap $\mathrm{M}_{6}$ LFN 2004. Hyde vs. Hyde (18611873) ALL ER 1753.

vii. Mojekwu vs. Ejikeme.

viii. Sometimes you children from some family having indelible features and characteristics of another family not related to them by blood. People just whisper especially if there was a suspicion of an affair. $\mathrm{C}_{23}$ LFN 2004.SS 3346. SS 13-24. Competing Interests in paternity cases: Iyilik vs. Turkey available at http:// strasbourgobservers. Com/2012/ 01/ 16/ competing interests-in-paternity cases-Iyilik-v-turkey/ accessed on 10/ 3/ 2016.

ix. Human Rights Convention. Paulik vs. Slovakia (App. No. 10699/ 05, 10 October 2006). Forensic Genetics Policy Initiative setting Human Rights standards for DNA Databases worldwide, (http;/ / dnapolicyinitiative.org).

X. $\quad$ S. 37. (1984) 2 SCR 173.(1924) 5 NWLR P. 33.

xi. S. 91.

xii. S. 18.

xiii. Article 1.

xiv. Article I. 